\title{
THB STRATIGRAPHY AND DEPOSITIONAL BNVIRONMENT OF UPPER ORDOVICIAN TO LOWBR DEVONIAN ROCKS IN THB ANTIGONISH HIGHLANDS, NOVA SCOTIA
}

\author{
J. B. Murphy \\ Department of Geology \\ St. Francis Xavier University, Antigonish \\ Nova Scotia, B2G 1 CO \\ Date Received July 1, 1986 \\ Date Accepted February 17,1987
}

\begin{abstract}
Upper Ordovician to lower Devonian rocks in the Antigonish Highlands, Nova Scotia, consist of bimodal volcanics and redbeds at the base overlain by a thick sequence of fossiliferous marine siliciclastic rocks. These rocks belong to the Arlsalg Group and correlate well with coeval rocks to the north of the Antigonish Highlands. The definition of the Arisaig Group is revised to include the uppermost Ordovician-lowermost Silurian Bears Brook Formation which occurs at the base, and the lower Devonian Knoydart Formation which occurs at the top of the succession.

The sequence as a whole is probably related to a local rifting event. The Bears Brook Formation consists of continental redbeds and bimodal rift-related volcanic rocks. A marine transgression at the base of the Silurian is Indicated by the first appearance of marine fossiliferous rocks and by the overstep relations exhibited by Silurian strata onto Precambrian basement. The marine transgression may have been associated with a world-wide eustatic rise in sea level and with local rifting. The Knoydart Formation is dominated by fluviatile redbeds indicating a return to subaerial conditions. The distribution of the Arisalg Group rocks around the southern and western margins of the Highlands together with the overstep relationships indicate that the Antigonish Highlands became progressively submerged during the Silurian. This was followed by a return to subaerial conditions in the Early Devonian.
\end{abstract}

Dans les Monts Antigonish, les roches de l'Ordovicien superieur au Dévonien inferieur comprennent un ensemble inferieur de volcanites bimodales et de lits rouges sur lequel repose une pulssante assise de roches fossiliferes marines silicoclastiques. Ces roches appartiennent au Groupe d'Arisalg et peuvent, alsément être corrélées avec leurs homologues au nord des Monts Antigonish. On redefinit le Groupe d'Arisaig pour y inclure la Formation de Bears Brook. présente en sa base et s'étageant du sommet de 1'Ordovicien au Silurien basal, ains1 que la Formation de Knoydart. du Dévonien inférieur et répartie au sommet de la succession.

Dans son ensemble, la séquence correspond probablement à un épisode local de rifting. La Formation de Bears Brook comprend des lits rouges continentaux et des volcanites bimodales apparenteses au rift. La premiere apparition de roches marines fossilifères et la discordance fondamentale entre les strates siluriennes et le bât1 précambrien témolgnent d'une transgression marine à l'amorce du Silurien. Cette incursion marine apparait relié à une remontée eustatique du niveau marin global ainsi qu'a un rifting local. L'Importance des lits rouges fluviatiles dans la Formation de Knoydart y atteste d'un retour a des conditions subaeriennes. La distribution des roches du Groupe d'Arisaig en bordures meridionale et occidentale des Monts ainsi que leur contact en discordance indiquent une submersion progressive des Monts Antigonish au cours du Silurien. L'Eodévonien marque un retour aux conditions subaeriennes.

[Traduit par le journal]

\section{INTRODUCTION AND GEOLOGICAL SETTING}

The Antigonish Highlands of northern Nova Scotia are bounded by the Hollow Fault to the north and west, by the Chedabucto Fault to the south and by Devonian-Carboniferous rocks in the east (Fig. 1). They are predominantly underlain by Precambrian rocks of the Georgeville Group (Murphy and Keppie. 1987) but also contain Cambrian-lower Ordovician (McDonalds Brook and Iron Brook groups) and uppermost Ordovician to lower Devonian (Arisaig Group) successions distributed at the extremities of the highlands (Fig. 1). The area lies within the Avalon Zone (Williams, 1978) or Avalon Composite Terrane (Keppie, 1985) of the Canadian Appalachians. Recent mapping in the Antigonish Highlands (Murphy, 1984, 1986) allows a re-evaluation of the stratigraphy and depositional environment of the Arisaig Group within the Antigonish Highlands and a comparison with the type area to the north of the Hollow Fault.
The Georgeville Group consists of a subaerially deposited bimodal sequence of felsic and mafic volcanic rocks overlain by a thick sequence of turbidites and minor mafic volcanics. These rocks suffered gentle folding in the south but were polydeformed by thrusts, isoclinal and upright folds in the north in the Late Precambrian. The Georgeville Group was intruded post-tectonically by appinitic gabbro and alaskite in the latest Precambrian (Murphy and Keppie, 1987). The Georgeville Group is unconformably overlain by two groups of Cambrian-1ower Ordovician rocks; the McDonalds Brook Group, which consists of red conglomerates at the base overlain by a sequence of bimodal volcanics and interlayered red slates, and the Iron Brook Group, which is comprised of red conglomerates and red slates overlain by fossiliferous pink limestones and slates followed by calcareous tuffs, ironstones and quartzites. These two groups are related by lateral facies variations (Murphy et al., in press). These rocks were deformed by 
Formation

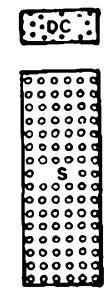

타탈

$\mathrm{E}_{\mathrm{S}}-\mathrm{C}$

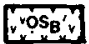

\section{Devono Carboniferous}

Knoydart

Stonehouse

Moydart

McAdam

French River

Ross Brook

Beechill Cove

Bears Brook

Cambrian - Lr Ordovician

Precambrian

BMF-Brown's Mountain Fault

MHF-Marshy Hope Fault

CF - Chedabucto Fault

HF - Hollow Fault

\section{Intrusives}

Deveno Carboniferous

NFi: Precambrian or Cambrian
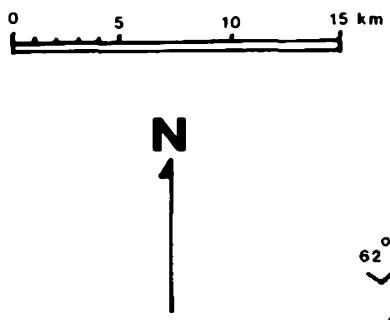

N

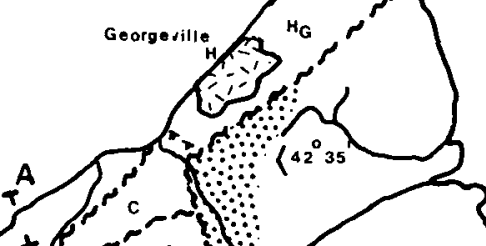

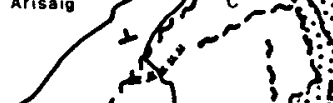

$P^{2}$ ?:<smiles>[AsH2][AsH2]</smiles>

तs

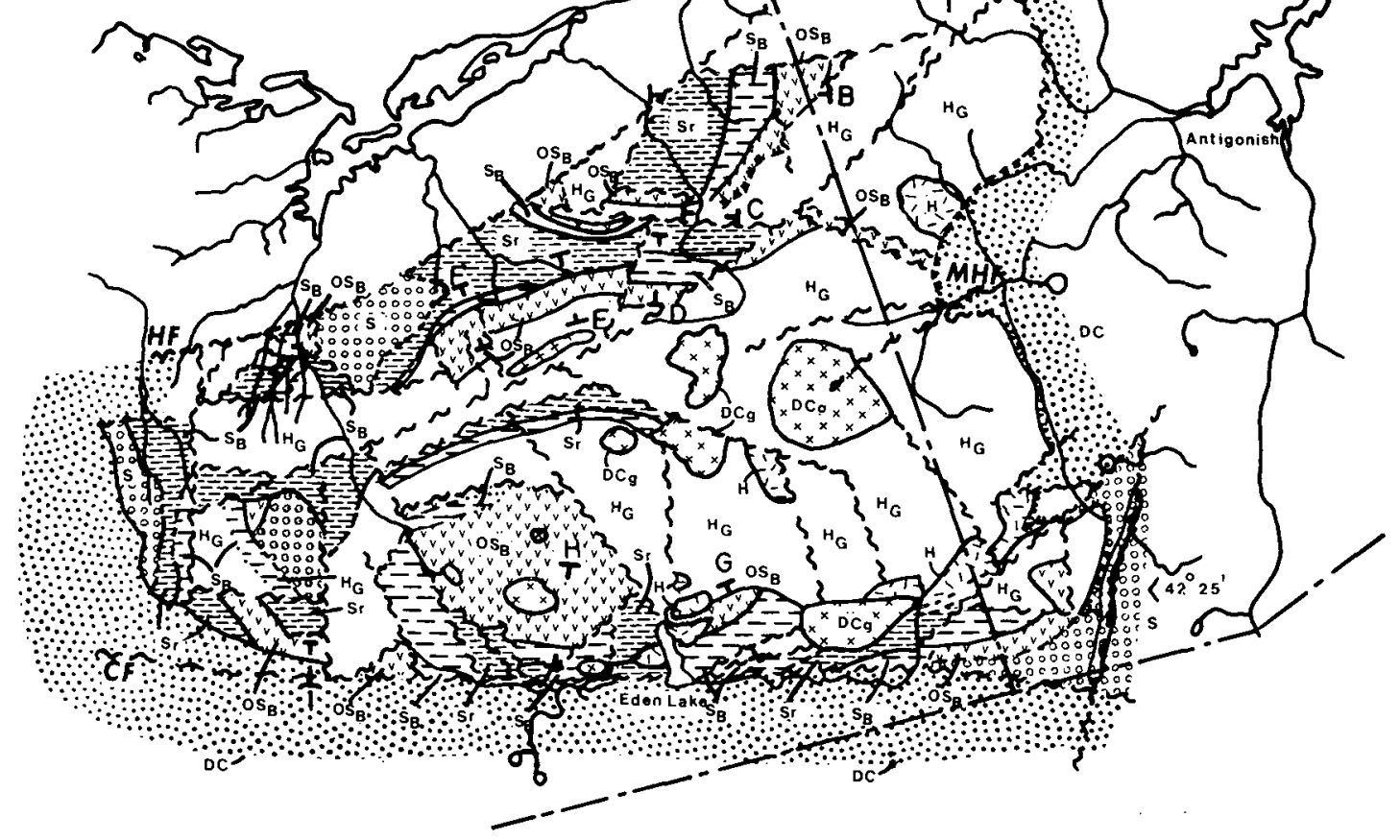

Fig. 1. Generalised geological map of the Antigonish Highlands showing the distribution of upper Ordovician-Silurian rocks. Inset shows location of the study area. Map simplified from Murphy et al. (1982). Murphy (1985). For details of Devono-Carboniferous rocks see Boehner and Giles (1982). The key to the units is given in Table 1. 
Table 1. Comparative stratigraphic interpretations of the Arisaig Group.

\begin{tabular}{|c|c|c|c|c|c|c|c|c|c|}
\hline \multirow{3}{*}{ 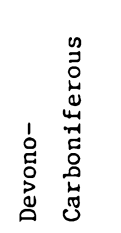 } & Boucot et al. 1974 & \multicolumn{4}{|c|}{ Maehl 1961} & \multicolumn{2}{|l|}{ Benson 1974} & \multicolumn{2}{|c|}{ Th is St udy } \\
\hline & Ar isaig Group & \multicolumn{2}{|r|}{ N. Ant igonish Highlands } & \multicolumn{2}{|c|}{ S. Ant igonish Highlands } & \multicolumn{2}{|c|}{ Ant igonish Highlands } & \multicolumn{2}{|c|}{ Ant igonish Highlands } \\
\hline & \multicolumn{9}{|c|}{ Undivided Devono-Carboniferous } \\
\hline 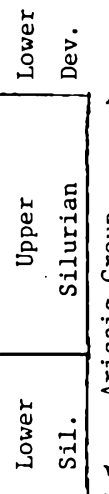 & $\begin{array}{l}\text { Knoydart Fm. } \\
\text { Stonehouse Fm. } \\
\text { Moydart Fm. } \\
\text { McAdam Brook Fm. } \\
\text { Doctors Brook Fm. } \\
\text { French River Fm. } \\
\text { Ross Brook Fm. } \\
\text { Beechnill Cove Fm. }\end{array}$ & $\mid \uparrow$ & $\begin{array}{l}\text { Knoydart Fm. } \\
\text { Stonehouse Fm. } \\
\text { Moydart Fm. } \\
\text { McAdam Fm. } \\
\text { French River Fm. } \\
\text { Ross Brook Fm. } \\
\text { Beechnill Cove Fm. }\end{array}$ & $\begin{array}{l}\text { Knoydart Fm. } \\
\text { Stonehouse Fm. } \\
\text { Kerrowgare Fm. } \\
\text { Glencoe Brook Fm. }\end{array}$ & $|\uparrow|$ & $\begin{array}{l}\text { Knoydart Fm. } \\
\text { Stonehouse Fm. } \\
\text { Moydart Fm. } \\
\text { McAdam Fm. } \\
\text { French River Fm. } \\
\text { Ross Brook Fm. } \\
\text { Beechnill Cove Fm. }\end{array}$ & 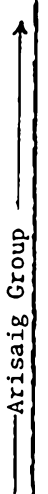 & $\begin{array}{l}\text { Knoydart Fm. } \\
\text { Stonehouse Fm. } \\
\text { Moydart Fm. } \\
\text { McAdam Fm. } \\
\text { French River Fm. } \\
\text { Ross Brook Fm. } \\
\text { Beechnill Cove Fm. }\end{array}$ & $\overbrace{[4]}^{\uparrow}$ \\
\hline 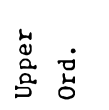 & $\begin{array}{l}\text { Bears Brook } \\
\text { Volcanic Group }\end{array}$ & & Bears Brook Fm. & Sunnybrae $\mathrm{Fm}$. & & Dunn Point Volcanics & & Bears Brook Fm. & [3] \\
\hline 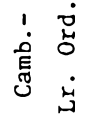 & Browns Mountain Grou & & Browns Mountain Group & $\begin{array}{l}\text { Charcoal Fm. } \\
\text { Browns Mount ain Group }\end{array}$ & & Browns Mountain Group & & $\begin{array}{l}\text { Iron Brook Macd } \\
\text { Group }\end{array}$ & $\begin{array}{l}\text { Id Brook } \\
o[2]\end{array}$ \\
\hline$\stackrel{\omega}{\sim}$ & & & & & & & & Georgeville Grour & {$[1]$} \\
\hline
\end{tabular}


thrusts, isoclinal and upright folds probably in the middle Ordovician (Murphy et al., in press). They are unconformably overlain by rocks of the Arisaig Group, which in this paper is revised to include the redbeds and bimodal volcanic rocks of the Bears Brook Formation overlain by a thick Silurian to lower Devonian sequence of fossiliferous siliciclastic rocks. The succession consists of (in ascending order) the Bears Brook, Beechill Cove, Ross Brook, French River, Doctors Brook, McAdam Brook, Moydart, Stonehouse and Knoydart formations. With the exception of the Bears Brook and French River formations, these formations have their type sections in the Arisaig area north of the Antigonish Highlands where they have been described in detail by Boucot et al. (1974). The Arisaig Group occurs predominantly around the southern and western margins of the Highlands flanking the Precambrian core (Fig. 1). Upper Ordovician to lower Silurian rocks are widely distributed, whereas middle Silurian to lower Devonian rocks are predominantly exposed at the western margin of the Highlands.

In the type area to the north of the Antigonish Highlands, the Arisaig Group is deformed by upright folds of middle Devonian age (Boucot et al., 1974); however in the Antigonish Highlands these rocks form monoclinal sequences except adjacent to major faults where thrusts and intense shearing occur. The Arisaig Group is unconformably overlain by Devono-Carboniferous rocks in the eastern and western extremities of the highlands (Boehner and Giles, 1982).

\section{PREVIOUS WORK AND DEFINITIONS}

Upper Ordovician-1ower Devonian rocks in the Antigonish Highlands have been studied in detail by Maeh1 (1961) and Benson (1974) and to the north of the Hollow Fault by Boucot et al (1974). A summary of the stratigraphy proposed by these authors is given in Table 1. Maeh1 (1961) divided the Arisaig Group into two distinct sequences (northern and southern highlands) which he interpreted to be lateral facies equivalents. In the northern highlands, he interpreted the Bears Brook Formation to be disconformably overlain by the Arisaig Group and to conformably overlie the Cambrian-Ordovician Browns Mountain Group (Table 1). In the southern highlands, he defined the Charcoa1, Sunnybrae and Kerrowgare formations. The Charcoal Formation was thought to comprise the upper part of the Browns Mountain Group, the Sunnybrae Formation was interpreted as a lateral equivalent to the Bears Brook Formation, the Glencoe Brook Formation as a lateral equivalent to the Beechill Cove Formation, and the Kerrowgare Formation as a lateral equivalent to the Ross Brook, French River and McAdam formations (Table 1).

The Charcoal Formation was described as consisting of $600 \mathrm{~m}$ of felsic and andesitic volcanics overlain in turn by $350 \mathrm{~m}$ of dark greygreen banded shales and slates (Sunnybrae Formation), $300 \mathrm{~m}$ of quartzites, sandstones and mudstones (Glencoe Brook Formation), and by $200 \mathrm{~m}$ of blue-grey and green siltstones, shales and slates (Kerrowgare Formation). These formations were interpreted by Maeh1 (1961) to be overlain by the Stonehouse and Knoydart formations.
Re-mapping of the western Antigonish Highlands (Murphy, 1986) indicates that the definitions of these formations are redundant because they are very similar to rocks of equivalent age in the northern Antigonish Highlands. Thus it is proposed here that these formations should be abandoned and replaced by their better known northern equivalents. The rocks assigned by Maeh1 (1961) to the Charcoal Formation are similar in lithology and in stratigraphic position to the Bears Brook Formation. The dark grey-green shales of the Sunnybrae Formation are generally similar to the Ross Brook Formation. This interpretation is supported by Benson (1967) who reported fossils typical of the Ross Brook Formation within the Sunnybrae Formation as defined by Maeh1. Therefore the contact between the Charcoal and Sunnybrae formations in the southern Highlands is reinterpreted herein as the overstepping of the Ross Brook Formation onto the Bears Brook Formation. In general the rocks assigned by Maeh1 (1961) to the Glencoe Brook Formation strongly resemble Beechill Cove facies 4 and 5 of Pickerill and Hurst (1983) in the type section of the Beechill Cove Formation. Furthermore Leptostrophia beechillensis, typical of the Beechill Cove Formation has been identified ( $R$. Pickerill, personal communication, 1985) from a sequence assigned by Maeh1 (1961) to the Glencoe Brook Formation. The Kerrowgare Formation lithologically resembles the French River and McAdam formations and similar fossils have been reported by Benson (1967). It is therefore recommended that the Charcoal, Sunnybrae, Glencoe Brook and Kerrowgare formations defined by Maeh1 in the southern Antigonish Highlands be abandoned because although there are some facies variations between the southern Highlands and the type area, the definitions of the formations in the type area can be applied to these rocks. The main difficulty in applying the definitions of the type area to the southern Highlands lies in the relatively poor quality of outcrop and in the intense localised deformation rather than in primary facies variations as envisaged by Maeh1 (1961).

Benson (1967, 1974) proposed a similar stratigraphic sequence to Maeh1 for the Arisaig Group in the northern Antigonish Highlands (Table 1). The main distinction between these authors occurs in the proposed stratigraphy of the southern Antigonish Highlands. Benson did not distinguish between sequences of the northern and southern Highlands (Table 1). For reasons outlined above, this author agrees with this interpretation.

Another important distinction between the sequences proposed by these authors concerns the stratigraphic position of the mafic to felsic volcanics that underly the Silurian fossiliferous siliciclastic rocks in the northern Highlands. Benson (1974) assigned the volcanic rocks to the Cambro-Ordovician Brierly Brook Formation of the Browns Mountain Group whereas Maeh1 (1961) included the volcanic rocks in the Bears Brook Formation (Table 1). This author agrees with the interpretation of Maeh1 (1961). Mapping (Murphy et al.. 1982; Murphy, 1986) shows that the Brierly Brook Formation as defined by Benson includes rocks that range from Late Precambrian to lowermost Silurian age and therefore the definition of this formation is in error. To the north of the Hollow Fault, Benson (1974) assigns a sequence of felsic 
and mafic volcanic rocks that disconformably underly the Silurian siliciclastic rocks (which he calls the Dunn Point Volcanics) to the uppermost Ordovician (Table 1). In this report, these rocks are interpreted as lateral equivalents of the Bears Brook Formation.

In general, the stratigraphy proposed by Benson (1974) and Maeh1 (1961) for the northern Antigonish Highlands closely corresponds with that of the type area of the Arisaig Group as defined by Boucot et al. (1974). However, the main difference between these authors lies in the interpretation of the sequence beneath the Beechill Cove Formation. In the Arisaig area, Boucot et al. (1974) re-defined and upgraded the Bears Brook Formation of Maeh1 (1961) to group status (the Bears Brook Volcanic Group, Table 1) and subdivided this group into three formations, the Dunn Point Formation overlain by the McGillivray Brook Formation with the Malignant Cove Formation laterally equivalent to both these formations. They interpreted the Bears Brook Volcanic Group to be disconformably overlain by the Beechill Cove Formation of the Arisaig Group and to unconformably overlie the Browns Mountain Group. However, on the basis of regional mapping in the northern Antigonish Highlands, Murphy et al. (1982) assign the Malignant Cove Formation to the MacDonald Brook Group and interpret it to be Early Cambrian in age. Therefore it cannot be a lateral equivalent to the Dunn Point and McGillivray Brook formations. In this study, the descriptor Bears Brook Formation is retained in preference to the Bears Brook Volcanic Group because it is argued (below) that the Bears Brook Formation forms part of a co-genetic sequence with the overlying formations of the Arisaig Group and therefore should be considered part of the Arisaig Group (Table 1).

Another minor difference between these authors lies in the spelling of the Beechill Cove Formation (Table 1). Maehl's (1961) spelling is the same as the geographic place-name and will be adopted in this paper.

Boucot et al. (1974) subdivided the McAdam Formation of Maeh1 (1961) into the Doctors Brook and McAdam Brook formations. The contact between these formations is placed where the black shales of the McAdam Brook Formation overly grey shales and thin (up to $5 \mathrm{~cm}$ ) siltstones of the Doctors Brook Formation. However, this distinction could not be made in the Antigonish Highlands. It is therefore proposed that all three formations should be retained, and that the McAdam Brook and Doctors Brook formations in the Arisaig area should be viewed as lateral facies equivalents of the McAdam Formation in the Antigonish Highlands.

THE ARISAIG GROUP IN THE ANTIGONISH HIGHLANDS

Age

In general, the lithology, stratigraphy and fauna of the Arisaig Group in the Antigonish Highlands are very similar to the type area of the Arisaig Group to the north of the Hollow Fault (Boucot et al., 1974) and correlations have been proposed by Maeh1 (1961) and Benson (1974). The extrapolation of these formations across the Hollow Fault is based on lithological, stratigraphic, paleontological and geochemical similarities. The distribution of the formations of the Arisaig Group is shown in Figure 1 and the place-names and type localities referred to in the text are shown in Figure 2. With the exception of the Bears Brook Formation, the age of these rocks is based on paleontological evidence (Maeh1, 1961; Boucot et al., 1974; Benson, 1974; Smith, 1979). Thus the Beechill Cove and Ross Brook formations are assigned to the Early Silurian, the French River, McAdam and Moydart formations to the Late Silurian and the Stonehouse and Knoydart formations to the Early Devonian.

The age of the Bears Brook Formation is less precisely known. On the basis of the above stratigraphic relationships, it lies between strata of lower Precambrian and Early Silurian age. To the north of the Antigonish Highlands, mafic and felsic volcanic rocks underlying the Beechill Cove Formation have been assigned to the Dunn Point and McGillivray Brook formations (Boucot et al., 1974). $\mathrm{Rb}-\mathrm{Sr}$ studies of the felsic volcanics in these formations have yielded an age of $421 \pm 11 \mathrm{Ma}$. (Fullager and Bottino, 1968, recalculated in Keppie and Smith, 1978) which, together with the stratigraphic context, suggests that these rocks are uppermost Ordovician or lowermost Silurian in age.

Recent $\mathrm{Rb}-\mathrm{Sr}$ analyses of the Bears Brook Formation show abundant scatter ylelding an "errorchron" of $425 \pm 37 \mathrm{Ma}$ (R. F. Cormier, personal communication, 1986). However, when taken in conjunction with the stratigraphic context and lithological association (i.e., these rocks underlie the lower Silurian Beech111 Cove Formation) it is probable that the Bears Brook Formation of Maeh1 (1961) is coeval with the Dunn Point and McGillivray Brook formations and is therefore uppermost Ordovician or lowermost Silurian in age.

Bears Brook Formation

Field Relationships:

The Bears Brook Formation of Maeh1 (1961) consists of red conglomerate, arkose, shale and interlayered mafic and felsic volcanic rocks. It unconformably overlies the Late Precambrian Georgeville Group and is conformably or disconformably overlain by arkoses and fossiliferous blue-green siltstones of the Beech 111 Cove Formation. The top of the Bears Brook Formation is placed at the uppermost volcanic rock that is stratigraphically beneath the fossiliferous siltstones. This definition coincides with that of the base of the Beechill Cove Formation from the type area (Boucot et al., 1974). The type section of the Bears Brook Formation is on Wallace Brook (Fig. 2, see also Maeh1, 1961). The formation is not exposed in Bears Brook; however, good sections are exposed on logging roads to the north and west of Bears Brook.

The Bears Brook Formation shows significant lithological variation across the fault blocks. For example, to the north of the Browns Mountain Fault (e.g., section D and E, Fig. 3), redbeds predominate and volcanic rocks are relatively minor. To the south of this fault redbeds are interlayered with mafic and felsic volcanic rocks in the western Highlands whereas in the southern Highlands felsic volcanic rocks predominate over mafic flows and redbeds (section $H$, Fig. 3). 


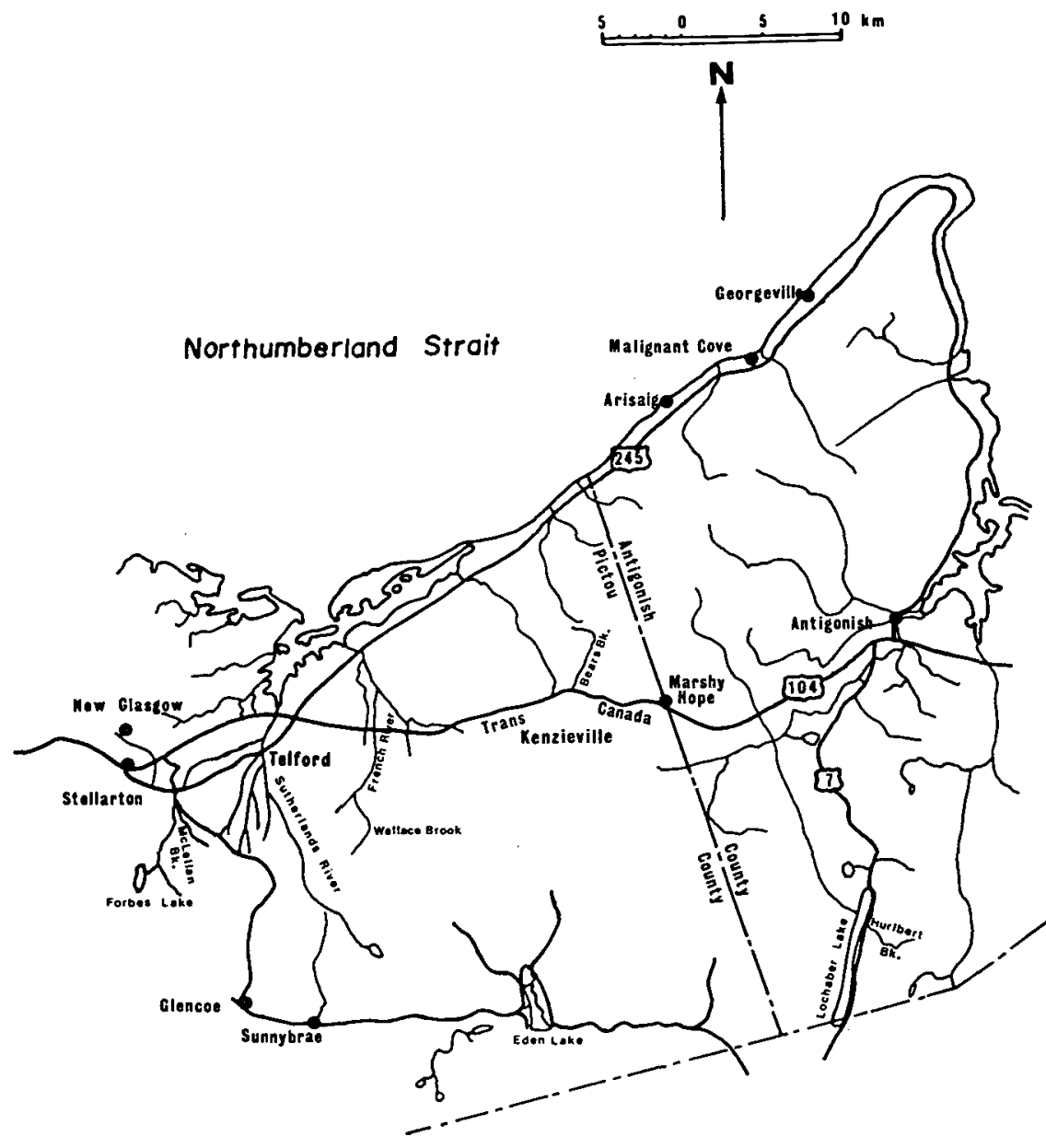

Fig. 2. Placenames mentioned in text.

Correlations across fault blocks are based on the similarity of the depositional environment and the stratigraphic position of the Bears Brook Formation between the Georgeville Group and the Beechill Cove Formation. Best exposures of the redbeds of the Bears Brook Formation occur on the Trans-Canada Highway in the Marshy Hope area. The mafic volcanic rocks and interlayered redbeds are well exposed on Wallace Brook and in the Sunnybrae area. The felsic volcanic rocks are best exposed in the Eden Lake area.

The thickness of the Bears Brook Formation is highly variable, mainly due to the changing thickness of the volcanic rocks. In the northern Highlands, the maximum thickness is about $200 \mathrm{~m}$ in the Wallace Brook area. In the southern highlands, the succession is at least $400 \mathrm{~m}$ thick.

\section{Description:}

Conglomerates and arkoses are massive and are typically red but may contain large irregularlyshaped green-stained patches. The conglomerates are poorly sorted and contain red silty and sandy lenses. They are deposited in channels up to $3 \mathrm{~m}$ across. The arkoses are we11-sorted and are characterised by "rip-up" clasts of red shale up to $5 \mathrm{~cm}$ in length. They display channels up to $5 \mathrm{~m}$ across with many examples of normal and inverse grading. Shales are relatively subordinate. They consist of beds varying from $1 \mathrm{~cm}$ to $1 \mathrm{~m}$ in thickness. The thinner beds are commonly discontinous on an outcrop scale.

The conglomerates and arkoses are polymictic, containing sub-angular to sub-rounded clasts of red and green shale, mafic and felsic volcanics, granite, diorite, quartz, albitised plagioclase, and, more rarely, sericitised orthoclase and disseminated pyrite. The matrix consists of finegrained clastic material, hematite, sericite, chlorite and epidote. Carbonate is variable in abundance and is most common adjacent to faults. The shales contain sub-rounded to sub-angular quartz in a matrix of hematite, chlorite and sericite.

Mafic volcanic rocks are green, massive and finegrained. They commonly contain amygdules filled with quartz, calcite, zeolites and pumpellyite. They occur in flows up to $3 \mathrm{~m}$ thick. In thin section, mafic volcanic rocks consist of thin laths of saussuritised plagioclase (albite-epidotecalcite) displaying flow texture. Some samples contain relict augite, partially altered to chlorite. Opaques (generally titaniferous magnetite) are highly variable in abundance and display both equant and interstitial textures. Apatite is spatially associated with magnetite. Alteration of these rocks has produced chlorite, 
Upper Ordovician-Lower Silurian Stratigraphy
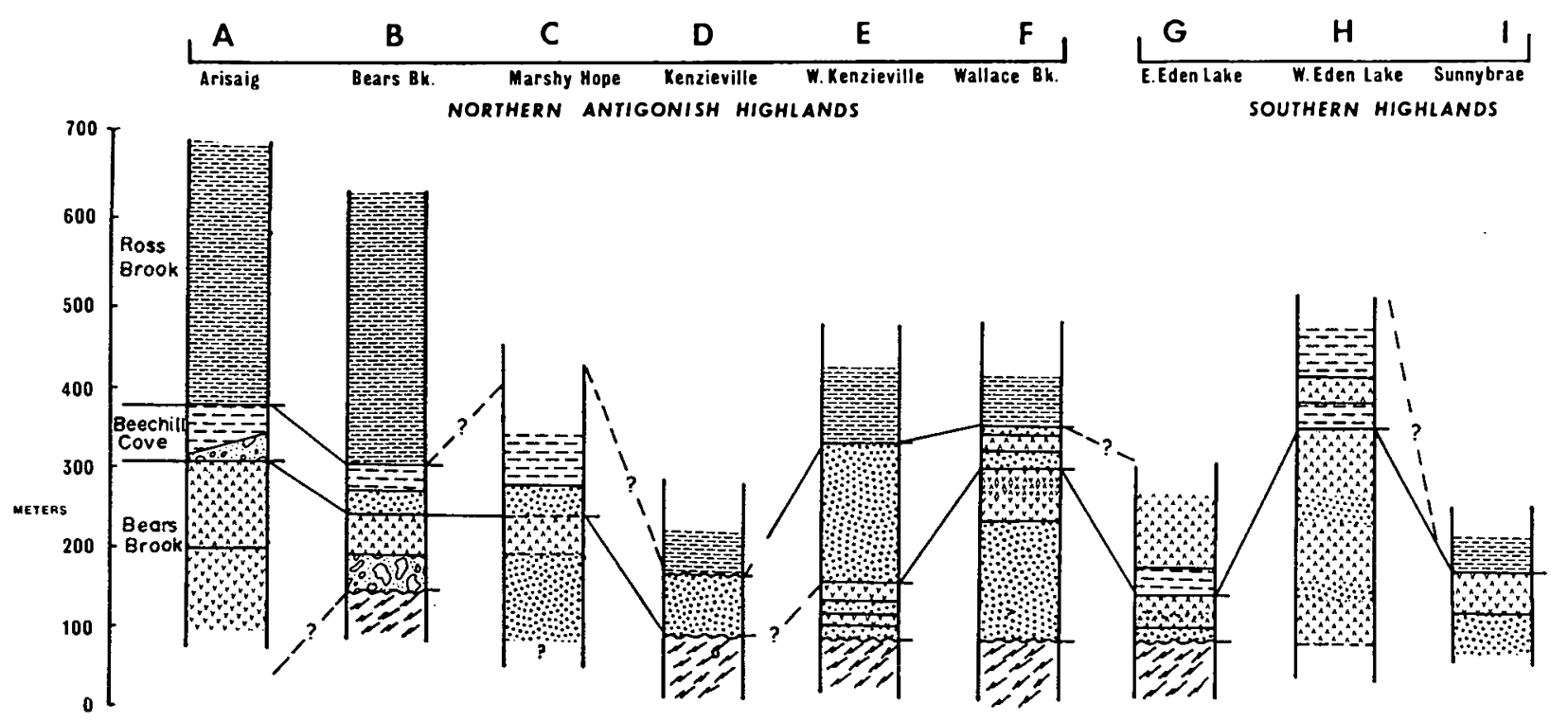

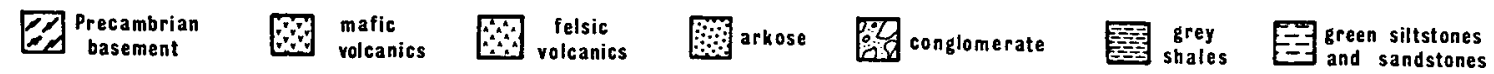

F1g. 3. Stratigraphy of upper Ordovician-Silurian rocks. Section A is generalised after Boucot et al. (1974), Keppie et al. (1978). P1cker111 and Hurst (1983), Hurst and Pickerill (1986). Locations of sections are shown in Fig. 1.

epldote, sphene, \pm actinolite, \pm quartz, \pm calcite, \pm rutile.

Felsic volcanic rocks consist of ignimbrites, tuffs and flows. Lahars are spatially assoclated with the felsic volcanics. These lithologies closely resemble those of the Precambrian felsic volcanic rocks of the Keppoch Formation, (Murphy, 1984) from which they can only be rellably distinguished by their stratigraphic position. Ignimbrites display pink to red banding that is approximately paralle1 to bedding. Good examples of banded ignimbrites occur in the Eden Lake area. Banding in the ignimbrites is defined in thin section by flattened pumice. They contain 11thic and crystal fragments up to $5 \mathrm{~cm}$ in length. The matrix is variably welded and consists of flattened, devitrified pumice and shards in a finegrained cryptocrystalline quartzo-feldspathic matrix. Non-welded ignimbrites contain we11preserved tricuspate shards. The 11thic fragments are almost exclusively of felsic composition and are generally less than $4 \mathrm{~mm}$ in size. Quartz phenoclasts are commonly cracked and embayed. Plagioclase is commonly saussuritised and altered to albite. Orthoclase phenoclasts are partly sericitised.

Tuffs contain 1ithic and crystal fragments up to $5 \mathrm{~cm}$ in length supported in a fine-grained ash matrix. They are massive, pale grey to red, and fine-grained containing angular fragments up to 1 $\mathrm{cm}$ in length. Flows are massive, pale grey to pink, and are generally aphyric though they may contain up to 10 percent saussuritised plagioclase phenocrysts up to $8 \mathrm{~mm}$ in length set in a cryptocrystalline quartzo-feldspathic matrix. Quartz phenocrysts, where present, are in part euhedral and in part embayed. Total phenocrysts rarely exceed 5 modal percent. Lahars consist of poorlysorted angular fragments of felsic and mafic volcanic rocks in a matrix dominated by chlorite and sericite.

\section{Beechill Cove Formation}

\section{Field Relationships:}

The Beechill Cove Formation can be subdivided into two informally proposed members. The lower member consists of up to $80 \mathrm{~m}$ of fluviatile arkoses and conglomerates. The upper member contains shallow marine fossiliferous massive blue-green siltstones, minor rhyolites and grey laminated siltstones. In most sections, the contact between the two members is sharp; however, minor interlayering occurs in some sections. The type area of the Beechill Cove Formation is north of the Hollow Fault near Arisaig. Boucot et al. (1974) did not subdivide the formation into informal members but did note that the basal portions consisted of conglomerates and pebbly sandstones which passed upward into blue-grey marine siltstones and shales. Fossil assemblages establish a lowermost Silurian age in the type area (Pickerill and Hurst, 1983) and similar assemblages occur in the Beechill Cove Formation in the Antigonish Highlands (Smith, 1979; R. Pickerill and J. Hurst, personal communication, 1984) also indicating a lower Silurian age.

The Beechill Cove Formation conformably to disconformably overlies the Bears Brook Formation and conformably underlies the Ross Brook Formation. Conformable relationships occur between the lower member of the Beechill Cove Formation and the Bears Brook Formation. Disconformable relationships 
occur where the lower member is absent. The top of the Beechill Cove Formation is defined by the first appearance of black micaceous mudstones (see Boucot et al., 1974) of the lower member of the Ross Brook Formation.

The lower member redbeds show considerable lateral variation in thickness. In some sections (e.g., the Trans-Canada Highway near Marshy Hope) they attain a thickness of about $80 \mathrm{~m}$ whereas in others the redbeds are absent (e.g., locality C, Fig. 3). The upper siltstone member commonly oversteps the Bears Brook Formation and rests unconformably on the Precambrian basement (Fig. 1). Laminated siltstones predominantly occur in the southern highlands (e.g., in the Eden Lake area where they disconformably overlie the Bears Brook Formation). This unit varies considerably in thickness. It is up to $20 \mathrm{~m}$ thick in the Eden Lake area; however, these rocks are commonly interlayered with a regular layered siltstone unit. The rhyolites are thickest in sections that also contain thick rhyodacites in the underlying Bears Brook Formation and are best exposed in the Eden Lake area. These rhyolites are not placed in the Bears Brook Formation because they are interlayered with or stratigraphically overlie the fossiliferous siltstones which occur at the base of the Beechill Cove Formation.

\section{Description:}

The conglomerates, arkoses and shales are virtually identical to those of the Bears Brook Formation. The distinction between the two formations in the field is based on their stratigraphic position with respect to the underlying felsic volcanic rocks of the Bears Brook Formation. The conglomerates and arkoses are red, display normal and inverse grading and are deposited in channels up to $5 \mathrm{~m}$ across. The siltstones are massive, blue-green in colour and contain abundant muscovite. In most localities, the blue-green siltstone contains abundant fossils in beds up to $30 \mathrm{~cm}$ in thickness. Weathered surfaces display characteristic limonitic staining. Fossils consist of brachiopods, trilobites, crinoids and corals (Smith, 1979; Pickerill and Hurst, 1983). The massive siltstones strongly resemble the "regular layered facles" (factes 4) of Pickerill and Hurst (1983) from the Beechill Cove Formation of the type area. The siltstones are lateraliy continuous and display sharp basal contacts. Fossils, where they occur, are found at the base of individual beds. The laminated siltstones resemble the "lenticular siltstone facies" (facies 5) of P1cker111 and Hurst (1983) in that they are plane-laminated with individual laminae (ranging up to $3 \mathrm{~cm}$ in thickness), they have sharp, planar basal contacts, and are laterally discontinuous. They occur only in the southern highlands.

Ross Brook Formation

\section{Field Relationships:}

The Ross Brook Formation conformably overlies the Beechill Cove Formation. However, in certain localities, the Ross Brook Formation oversteps the Beech111 Cove Formation to rest direct1y on the
Bears Brook Formation or the Precambrian basement. An excellent example of this occurs at Sunnybrae on Glencoe Brook where the Ross Brook Formation rests on the Bears Brook Formation (section I, Fig. 3). There is evidence of reworking of the Bears Brook Formation at this contact.

The lower contact with the Beechill Cove Formation is placed at the first appearance of black or dark grey shales. The upper contact with the French River Formation is defined by a sharp colour and 1ithological change from dark shales to pale green siltstones (Maeh1, 1961; Boucot et al., 1974). The Ross Brook Formation is best exposed in the Kenzieville area, particularly on French River where it may be subdivided into lower and upper members based on the absence or presence (respectively) of massive sandstones or siltstones interbedded with the shales. The lower member varies from 30 to $100 \mathrm{~m}$ in thickness. The upper member is only exposed on French River where it is about $100 \mathrm{~m}$ thick.

\section{Description:}

The Ross Brook Formation consists of black to grey fossiliferous bioturbated micaceous shales (lower member) overlain by an interlayered sequence of grey-black to blue-grey shales and massive or cross-laminated fossiliferous siltstones and sandstones (upper member, compare Hurst and Pickeril1, 1986).

The shales are poorly laminated and fissile. Weathered surfaces display limonitic staining. They are abundantly fossiliferous containing brachiopods, trilobites, crinolds, gastropods and, more rare1y, graptolites (see Maeh1, 1961; Benson, 1974). The sandstones and siltstones are grey, typically massive or cross-laminated and are resistant to erosion. They generally weather to a pale brown or orange colour.

\section{French River Formation}

\section{Field Relationships:}

The French River Formation conformably overlies the Ross Brook Formation. The lower contact is defined by a sharp change in colour from grey shales of the Ross Brook Formation to paler sandstones and siltstones of the French River Formation. In the study area, the French River Formation is only identified on French River (the type section, see Maeh1, 1961) and in limited exposures on Sutherlands River probably because it is difficult to distinguish from the overlying McAdam Formation due to poor exposure. The upper contact with the overlying McAdam Formation is gradational and is defined by the relative dominance of siltstones and shales over sandstones in the McAdam Formation. In the type section, the French River Formation is about $60 \mathrm{~m}$ thick.

\section{Description:}

The French River Formation is dominated by bluegrey micaceous sandstones and siltstones with subordinate shales. A set of fractures that are perpendicular to bedding give these rocks a blocky appearance. They contain abundant fossils, especially brachiopods and crinoids. Individual 
units are up to $30 \mathrm{~cm}$ in thickness and commoniy display grading from a siltstone or sandstone base to shaley tops. The shales are commonly laminated, though the laminae are generally disturbed probably as a result of bioturbation. Sandstones and siltstones are composed of angular to sub-angular quartz, albite and muscovite with relatively minor pyrite in a matrix consisting predominantly of sericite, chlorite and minor calcite.

\section{McAdam Formation}

\section{Field Relationships:}

The McAdam Formation conformably overlies the French River Formation. This contact is gradational and is arbitrarily placed where grey shales of the McAdam Formation predominate over blue-grey sandstones and siltstones of the French River Formation. The upper contact with the overlying Moydart Formation is also gradational and is defined where green shales of the Moydart Formation predominate over darker shales of the McAdam Formation. The thickness of the McAdam Formation in the study area is difficult to determine due to poor exposure. However, on Sutherlands Brook in the Telford area, the formation is estimated to be about $200 \mathrm{~m}$ thick. The McAdam Formation is also exposed on logging roads in the Forbes Lake area in the western Antigonish Highlands.

\section{Description:}

The McAdam Formation is dominated by grey massive cross-laminated siltstone at the base with minor interbedded grey mudstone. The grey mudstone becomes dominant towards the middle of the formation. Individual siltstone units range up to $25 \mathrm{~cm}$ in thickness and resemble those of the Ross Brook Formation. However, as noted by Maeh1 (1961), the siltstones of the McAdam Formation may be distinguished from the Ross Brook Formation in that their abundance decreases rapidly up-section. Furthermore they are generally calcareous. Brachiopods and crinoids are abundant throughout this formation. The siltstones consist of we11sorted sub-angular to sub-rounded quartz, with relatively minor plagioclase and muscovite. The matrix consists of hematite, sericite, chlorite, calcite and clay minerals. The shales are similar in composition to the matrix of the siltstones.

Near the middle of the formation the grey shales are overlain by dark to black fissile shales and in turn by grey shales. The dark shales are characterised by the presence of calcareous nodules up to $50 \mathrm{~cm}$ in diameter.

\section{Moydart Formation}

\section{Field Relationships:}

The Moydart Formation may be divided into a lower green and an upper red member (Maeh1, 1961). The lower contact with the underlying McAdam Formation is gradational and is placed where green-grey shales predominate over the darker shales of the McAdam Formation. The upper contact with the overlying Stonehouse Formation is conformable and is defined at the uppermost appearance of red shale. The Moydart Formation is best exposed in the Telford area, in fault slices on McLellans Brook, and on the west side of Lochaber Lake. The thickness of the lower member is about $90 \mathrm{~m}$ and the upper member is about $10 \mathrm{~m}$.

\section{Description:}

The lower member consists of green sandstones, siltstones and shales. The sandstones are massive, hard and micaceous. The siltstones are laminated and in some instances display cross-lamination and commonly display graded bedding with shaley tops. Shales are the dominant lithology especially towards the top of the member. Ripple marks occur at the top of some of the siltstone units. The green member of this formation contains abundant brachiopods and crinoids. The upper member consists of interbedded red, purple and green shales. They have a mottled appearance, are moderately calcareous and have calcareous nodules.

The siltstones and sandstones consist of between 35 and 60 percent sub-rounded to angular quartz with lesser amounts of plagioclase, and muscovite in a matrix of sericite, chlorite, calcite and clay minerals. The shales are similar in composition to the matrix of the siltstones. The red shales also contain abundant hematite.

Stonehouse Formation

Field Relationships:

The Stonehouse Formation conformably overlies the Moydart Formation. The contact is defined at the uppermost red shale unit of the Moydart Formation. The upper contact is placed at the uppermost green unit that is conformably overlain by the redbeds of the Knoydart Formation. The Stonehouse Formation is best exposed in the Forbes Lake area in the western Antigonish Highlands and on the west side of Lochaber Lake in the southeastern Highlands. Thickness estimates are difficult due to incomplete exposure but in the Forbes Lake area, the Stonehouse Formation is probably at least $600 \mathrm{~m}$ thick.

\section{Description:}

As noted by Maeh1 (1961), the lower part of the Stonehouse Formation resembles the green member of the Moydart Formation. These rocks are green-grey to blue-grey, micaceous siltstones and commonly have well-developed laminated tops that commonly display cross-lamination. Blue-grey siltstones predominate in the middle of the formation and towards the top of the sequence minor red shales occur. The Stonehouse Formation is very fossiliferous containing brachiopods and crinoids. Although Copeland (1964) reports ostracodes from this formation in the Arisaig area, none were positively identified in the Antigonish Highlands.

\section{Knoydart Formation}

Field Relationships:

The relationship of the Knoydart Formation with the underlying Stonehouse Formation and with the overlying McAras Brook Formation is not exposed in the area. However, Boucot et al. (1974) document a 
gradational contact between the Stonehouse and Knoydart formations in the Arisaig area, and on McAras Brook the Knoydart Formation. Is unconformably overlain by the McAras Brook Formation. The Knoydart Formation is best exposed near Lochaber Lake. Thickness is difficult to estimate due to non-exposure of the contacts but on Hurlbert Brook, to the east of Lochaber Lake, the section is at least $500 \mathrm{~m}$ thick. No fossils were found in the Knoydart Formation in the Antigonish Highlands.

\section{Field Description:}

The Knoydart Formation consists of red, purplishred and grey-red conglomerate, siltstone and shale with minor green shale. The conglomerates are poor $1 y$ - to we11-sorted and contain fragments up to $20 \mathrm{~cm}$ in diameter. These fragments consist of granite, felsic volcanic rocks, red and green sandstones and shales in a fine-grained matrix dominated by quartz, hematite, calcite, sericite and chlorite. Granite fragments consist of quartz and saussuritised feldspar displaying graphic intergrowths. Felsic volcanic fragments contain microphenocrysts of plagioclase in a partly sericitised cryptocrystalline quartzo-feldspathic groundmass. Sandstone clasts are well-sorted and are compositionally dominated by sub-rounded quartz with minor feldspar in a hematitic matrix. Shale fragments are very similar to the red and green shales of the Arisaig Group. The siltstone and shale that are interlayered with the conglomerates are micaceous. The siltstones are commonly graded and cross-laminated. The shales characteristically contain abundant pale green calcareous nodules up to $5 \mathrm{~cm}$ in diameter. Poorly-preserved brachiopods were found in the green shales near Lochaber Lake. The assignment of these rocks to the Knoydart Formation is based. on the strong lithological comparison of these rocks to the type section at Knoydart (compare Boucot et al., 1974).

At Lochaber Lake, two cleavages, a C cleavage which is parallel to bedding and a S cleavage which is generally at about $30^{\circ}$ to bedding (see Berthe et al.. 1979) are we11-developed in all 1ithologies adjacent to the Lochaber Lake Fault. Fragments are intensely flattened and stretched and are elongate parallel to the $\mathrm{S}$ cleavage.

\section{CORRELATION}

The stratigraphy of the Arisaig Group in the type area (Boucot et al., 1974) and in the Antigonish Highlands (this study) is shown in Table 1 . In general the two sequences correlate favourably and similar definitions of the boundaries between formations may be applied in both areas. Selected stratigraphic sections of uppermost Ordovician to lower Silurian rocks of the Antigonish Highlands are shown in Figure 3. For comparative purposes, an idealised section of the type area (section A) of the Arisaig Group (compiled from Boucot et al., 1974; Keppie et al., 1978; Pickerill and Hurst, 1983; and Hurst and Pickerill, 1986) is also presented.

The Bears Brook Formation is considered to be laterally equivalent to the Dunn Point and McGillivray Brook formations. A11 these formations contain abundant volcanic rocks and display evidence of subaerial deposition. The most important 1ithological difference between these formations is that the Bears Brook Formation contains abundant red conglomerates and arkoses and displays significant lateral variations in the relative abundance of each lithology and in thickness (Fig. 3). The Dunn Point and Bears Brook formations both contain bimodal volcanic rocks. The chemistry of the volcanic rocks in these formations is virtually indistinguishable (Murphy, 1987). The geochemistry of the volcanic rocks of the Bears Brook Formation probably reflects a continental, within plate extensional tectonic environment. Keppie et al. (1978) propose a similar interpretation for the Dunn Point and McGillivray Brook formations.

The spatial and temporal association of both of these volcanic sequences with the Beechill Cove Formation, indicates that these formations document a broadly co-genetic sequence. This is supported by the similarity between the sedimentary rocks of the Bears Brook and the lowermost facies of the Beechil1 Cove Formation and by the probable uppermost Ordovician or lower Silurian age indicated by the $\mathrm{Rb}-\mathrm{Sr}$ isotopic data.

It is proposed that the Bears Brook, Dunn Point and McGillivray Brook formations should be included in the Arisaig Group. According to Article 19 of the North American Stratigraphic Code a revision of the boundary of a unit is justifiable "if a minor change in the boundary or content will make the unit more natural or useful". Although the definition of the Arisaig Group is well-established in the literature as a succession of fossiliferous siliciclastic rocks, the revision is proposed because :

(i) the contact between the Bears Brook and Beechill Cove formations is conformable in the Antigonish Highlands. This indicates that the disconformity between the Beechill Cove Formation and the underlying volcanic rocks in the Arisaig area represents another example of overstepping due to marine transgression rather than a significant break in the sequence.

(ii) rhyolites occur within the Beechill Cove Formation within the Antigonish Highlands. Thus the exclusion of volcanic rocks from the Arisaig Group is not warranted. The rhyolites are chemically distinct from the rhyodacites of the Bears Brook and Dunn Point formations but they are virtually indistinguishable from the rhyolites of the McGillivray Brook Formation. The rhyolites in both formations are anomalously high in $\mathrm{Si}$, and low in $\mathrm{Mg}, \mathrm{Fe}, \mathrm{Ti}$ and $\mathrm{Sr}$ (Murphy, 1987).

(iii) the geochemistry of the volcanic rocks records a continental rift-related tectonic setting. A marine transgression at the base of the Silurian documented by the first appearance of marine fossiliferous strata is consistent with this environment. Thus the volcanic and siliciclastic rocks probably form a co-genetic sequence.

It is therefore suggested that the inclusion of the Dunn Point, McGillivray Brook and Bears Brook formations into the Arisaig Group makes the definition of the Arisaig Group "more natural and usefu1".

For similar reasons, the Knoydart Formation should also be considered part of the Arisaig Group because as noted by Boucot et al. (1974) the Knoydart Formation rests conformably on the 
Stonehouse Formation. Although the Knoydart Formation is dominated by redbeds (in contrast to the underlying Stonehouse Formation) the exclusion of the Knoydart Formation from the Arisaig Group on 1ithologic grounds is not warranted because redbeds also occur within the Moydart Formation. It is suggested that the Knoydart Formation forms part of a co-genetic sequence within the Arisaig Group and represents a regressive stage in the depositional history.

In summary, the revised Arisaig Group represents a continuous sequence of uppermost Ordovician to lower Devonian sedimentary and volcanic strata. It unconformably overlies Precambrian and Cambrianlower Ordovician sequences and is unconformably overlain by the upper Devonian McAras Brook Formation. As such it represents an almost complete sequence between the Taconic and Acadian orogenic events.

In general, the stratigraphy of the Beechill Cove and Ross Brook formations in the Antigonish Highlands compares favourably with the type area. The main difference is the occurrence of a thin volcanic unit (generally felsic) within the Beechill Cove Formation in the Antigonish Highlands (sections $\mathrm{F}$ and $\mathrm{H}, \mathrm{Fig}$. 3). Two dominant lithologies have been recognised in the Beechill Cove Formation in the Antigonish Highlands, a lower member dominated by red fluviatile conglomerates and arkoses and an upper member which consists of mottled, massive, fossiliferous, shallow marine siltstones. Locally (e.g., the Glencoe Brook area) quartzites and laminated siltstones also occur. In the type area, near Arisaig, Pickerill and Hurst (1983) document six facies. Facies 1 consists of a thin oligomictic conglomerate deposited as a transgressive beach lag, facies 2 is composed of red shales deposited in a shoreface environment, facies 3 is dominated by mottled mudstones interpreted as a shallow subtidal deposit, facies 4 is a regular layered turbiditic siltstone deposited in a shelf environment with a periodically high energy environment of deposition, facies 5 contains lenticular siltstones deposited in a subtidal environment, and facies 6 is a laminated shale deposited in a low energy environment (see Fig. 2 of Pickerill and Hurst, 1983).

The lower 1ithology of the Beechill Cove Formation in the Antigonish Highlands is probably a lateral varlation of facies 1 and 2 of Pickerill and Hurst (1983). In both the Antigonish Highlands and Arisaig these lithologies overlie volcanic rocks and underly fossiliferous siltstones. However, in the type area, facies 1 has been interpreted as a transgressive beach lag deposit (Picker111 and Hurst, 1983) whereas the lateral equivalent in the Antigonish Highlands represents a fluviatile environment. The upper 1ithology in the Antigonish Highlands is very similar to facies 4 in that it is laterally continuous and commoniy contains thick graded shell layers at the base of the siltstone units. These layers contain the Lepostrophia beechillensis faunal association ( $R$. $\mathrm{K}$. Pickeril1, personal communication, 1985) that is typical of the Beechill Cove Formation.

Boucot et al. (1974) divided the Ross Brook Formation into three members. The lower member consists of black shales, the middle member is distinguished by a gradual change in colour from black to grey together with interbedded siltstones and the upper member contains an increased proportion of siltstones interbedded with the shales. The lower member of the Antigonish Highlands is very similar to the lower and middle members of Boucot et al. (1974) whereas the upper member of the respective areas is virtually identical.

The French River Formation was proposed by Maeh1 (1961) for the rocks that conformably overlie the Ross Brook Formation on French River in the northwest Antigonish Highlands. On paleontological and lithological grounds, Boucot et al. (1974) defined the French River Formation in the equivalent stratigraphic position in the Arisaig area, i.e., where a sharp colour change separates the lower grey shales of the Ross Brook Formation and the green siltstones of the French River Formation.

The Doctors Brook Formation is not represented in the Antigonish Highlands. This is probably because exposures in the Antigonish Highlands are not of sufficient quality to identify this formation. Furthermore the definition of the lower contact of the Doctors Brook Formation with the French River Formation in the Arisaig area is based on the relative dominance of siltstones and shales and this definition may have only local applications. It is doubtful whether such a definition can have regional applications. The French River Formation as defined by Maeh1 (1961) and accepted here may encompass both the French River and Doctors Brook formations as defined by Boucot et al. (1974).

Boucot et al. (1974) defined the base of the McAdam Formation by the occurrence of black shales. This 1ithology was not found in the Antigonish Highlands; the lower boundary with the French River Formation is defined on the greater abundance of shales in the McAdam Formation. This makes the contact difficult to define in poorly-exposed and structurally complex areas (e.g., near the Chedabucto Fault).

The definitions of the Moydart, Stonehouse and Knoydart formations as described by Boucot et al . (1974) apply to the Antigonish Highlands. Maeh1 (1961) and Benson (1967, 1974) have described faunas similar to those of Boucot et al. (1974) in each of the respective formations.

\section{DEPOSITIONAL ENVIRONMENT}

In general the stratigraphic sequence records a marine transgression during the lowermost Silurian with subaerially deposited rocks (Bears Brook and lower Beechill Cove formations) overlain by shallow marine clastics (upper Beechill Cove and Ross Brook formations). The presence of welded ignimbrites, abundant red clastic sediments, and rapid lateral variations in lithology and in the thickness of the sequence suggest a subaerial environment of deposition for the Bears Brook and lower Beechill Cove formations in which there was substantial paleotopographic control. The textures of the red conglomerates and arkoses suggest a fluviatile environment of deposition. This is consistent with the red colour, the presence of normal and inverse grading, locally irregular bedding, the abundance of channels up to $5 \mathrm{~m}$ across, and the abundance of "rip-up" clasts of red shale within the conglomerates.

In detail, the Bears Brook Formation is characterised by rapid and locally controlled 
lateral 1ithological variations. For example, sections $B$ and C (Fig. 3), taken only $4 \mathrm{~km}$ apart, are dominated by coarse-grained conglomerates (with pebbles up to $10 \mathrm{~cm}$ ) and by fine-grained arkosic sandstones respectively. Local variations in lithology, texture and degree of angularity of the fragments displayed in the conglomerates suggest that they have a fanglomeratic component. Volcanic rocks within this formation are highly variable in abundance and are most abundant adjacent to major faults such as the Browns Mountain and Chedabucto faults. The mafic volcanic rocks are relatively subordinate or are absent from many sections. Felsic volcanic rocks (flows, ignimbrites and tuffs) are invariably present and are especially dominant in the southwestern highlands (section $\mathrm{H}$, Fig. 3). These pronounced lateral variations in the distribution of the volcanic rocks indicate a significant paleotopographic control.

The most important facies variations occur north and south of the Browns Mountain Fault (BMF) in contrast with the lack of lithological variations across the Hollow Fault. To the south of BMF, felsic volcanic rocks are dominant (compare sections $A, B$ and $E$ with sections $F$ and $G$, Fig. 3 ). This suggests that the southern Antigonish Highlands was a centre of felsic volcanic activity in the latest Ordovician-earliest Silurian and that the Browns Mountain Fault was either tectonically active or had significant topographic expression (or both) at that time.

Pickerill and Hurst (1983) interpret the lower Beechill Cove facies north of the Antigonish Highlands to be a transgressive beach lag deposit. In contrast, in the Antigonish Highlands, volcanic rocks are overlain by a thick sequence of arkose and conglomerate. The similarity of the arkose and conglomerate to those in the Bears Brook Formation suggests that they were probably deposited in a similar fluvial environment to the Bears Brook Formation. These relationships indicate that the shoreline during earliest Silurian times was probably in the vicinity of the present day Hollow Fault.

Fossiliferous siltstones of the Beechill Cove Formation represent the first marine rocks of the Arisalg Group. Pickerill and Hurst (1983) interpret the "regular layered" siltstones to be deposited by storm-generated turbidity currents in a subtidal marine shelf sequence and the laminated siltstones to represent a shallow subtidal environment.

The relative homogeneity of the upper Beechill Cove and Ross Brook formations and the presence of shallow marine fossils indicate that the Antigonish Highlands progressively became submerged. This is supported by the distribution of Silurian rocks at the extremities of the Highlands and is further indicated by overstep relationships shown in Figures 1 and 3 . For example, the Beechill Cove Formation may rest directly on basement (see $X$, Fig. 1) or the Ross Brook Formation may rest on the Bears Brook Formation (see Y, Fig. 1). In some instances the contacts between formations of the Arisaig Group are locally unconformable. The above discussion supports the interpretations of Pickerill and Hurst (1983) that the Beechill Cove Formation represents a transgressive sequence. The distribution of the clastic rocks at the margins of the Antigonish Highlands suggests that rocks of the
Arisaig Group draped the Antigonish Highlands.

The marine transgression at the base of the Silurian has been associated with a world-wide eustatic marine transgression (e.g., Cant, 1980). The synchroneity between rifting (as indicated by the geochemistry of the volcanic rocks ( Keppie et al., 1979; Murphy, 1987) and the eustatic rise in sea level may be responsible for the almost complete sequence of uppermost Ordovician to lower Devonian strata deposited in the Antigonish-Arisaig area. Throughout the Silurian the sequence is dominated by shallow marine siliciclastic rocks. There are no large scale coarsening- or finingupward sequences and fluctuations in the energy of the depositional environment appear to be on a relatively small scale. This suggests that sedimentation was able to keep pace with eustatic changes in sea level. Cant (1980) and Pickerill and Hurst (1983) suggest that sedimentation of the Arisaig Group in the type area was governed by periodic storm activity and a similar model is possible in the Antigonish Highlands.

Uppermost Silurian to lower Devonian strata show an increasing abundance of red shale and conglomerate which indicates a gradual shallowing of the environment of deposition and a return to subaerial deposition.

\section{CONCLUSIONS}

The definition of the Arisaig Group is revised to include the uppermost Ordovician to lowermost Silurian Bears Brook Formation, the laterally equivalent Dunn Point and McGillivray Brook formations and the lower Devonian Knoydart Formation. This revision means that the Arisaig Group occupies a strategic position in the history of the Appalachians in that it records an a1most complete sequence of rocks that were deposited between the Taconic and Acadian orogenic events.

It is recommended that the Charcoal, Sunnybrae, Glencoe Brook and Kerrowgare formations defined by Maeh1 (1961) for the southern Antigonish Highlands be abandoned because rocks assigned to these formations are similar to those of the northern Antigonish Highlands. Thus these names should be replaced by the better known northern equivalents.

The Arisaig Group in the Antigonish Highlands was deposited in a continental to shallow marine, within plate, extensional environment. Rifting resulted in bimodal volcanism and a marine transgression in which continental clastic rocks are overlain and overstepped by marine fossiliferous rocks. The Bears Brook Formation and the lower member of the Beechill Cove Formation were deposited in a fluvial environment in contrast to the laterally equivalent beach lag rocks to the north of the Hollow Fault. This suggests that the shoreline at uppermost Ordovician-lowermost Silurian time was probably close to the present-day trace of the Hollow Fault. The marine transgression was probably due to the synchroneity of local rifting (Murphy, 1987) and the eustatic rise in sea leve1 (Cant, 1980).

The Beechill Cove Formation north and south of the Hollow Fault is 1ithologically and paleontologically similar. Pickerill and Hurst (1983) interpreted this formation north of the Hollow Fault as a transgressive marine sequence and an analogous interpretation is offered here for these 
rocks in the Antigonish Highlands. The lack of coarsening- or fining- upward sequences within the upper Silurian rocks indicates that sedimentation was able to keep pace with eustatic changes in sea leve1.

The most significant lateral variations were found across the Browns Mountain Fault rather than the Hollow Fault. This suggests that there may be some difficulties in evaluating regional correlations, i.e., they may be difficult to separate from local controls. Assuming that the Bears Brook Formation was once continuous across the Browns Mountain Fault, displacement across the Fault is less than $5 \mathrm{~km}$.

In the simplest sense, the similarities between these successions north and south of the Hollow Fault suggests that they were once continuous. This therefore restricts cumulative post-1ower Silurian movement on the Hollow Fault to about 40 $\mathrm{km}$ in a dextral sense. This may have significant implications on palinspastic reconstructions. Alternatively, if future work on rocks of this age in the Appalachians shows that these types of successions are common, then significantly more movement may be accommodated.

\section{ACKNOWLEDGEMENTS}

I wish to thank Duncan Keppie and Fred Chandler for their continuing interest in the geology of the Antigonish Highlands, Ron Pickerill for help with fossil identification and Gary Yeo for discussions. Support for field work by the Geological Survey of Canada, (under the E.R.D.A. agreement) and by N.S.E.R.C. is gratefully acknowledged. Thanks to K. Bellefontaine, P. Campbe11, K. Chisholm, D. Hatchette, E. Myketyn and S. Sears who assisted on various parts of this work and to $M$. Doherty for typing. Constructive reviews by R.K. Pickerill and J.D. Keppie and comments by G.L. Williams and C.A. Larocque resulted in significant improvements to the manuscript.

BENSON, D.G. 1967. Geology of the Hopewell map-area. Geological Survey of Canada. Memo1r 343. $58 \mathrm{p}$.

BENSON. D.G. 1974. Geology of the Ant1gon1sh Highlands, Nova Scot1a. Geological Survey of Canada, Memo1r 376, 92 p.

BERTHE, D. CHOUKROUNE, P. and JEGOUZO, P. 1979. Orthogne1ss, mylonite and non-coaxial deformation of granites, the example of the South Armorican Shear Zone. Journal of Structural Geology. 1. pp. 31-42.

BOEHNER, R.C. and GILES, P.S. 1982. Geological map of the Ant1gonish Basin, Nova Scotia. Nova Scotia Department of M1nes and Energy. Map 82-2, Scale 1:50,000.
BOUCOT, A.J., DEWEY, J.F., DINELEY, D.L, FLETCHER, R., FYSON, W.K. GRIFFIN, J.G. . HISKOX, C.F. MCKERROW, W.S., and ZEIGLER A.M. 1974. Geology of the Arisa1g area, Antigonish County, Nova Scot1a, Special Paper 139, 191 p.

CANT, D.J. 1980. Storm deposited shallow marine sediments of the Arisaig Group (S1lurlan-Devonian) of Nova Scotia. Canadian Journal of Earth Sciences, 17, pp. 120-131.

COPELAND, M.J. 1964. Canadian foss11 Ostracoda: some Silurian species. Geological Survey of Canada, Bulletin 117, $20 \mathrm{p}$.

FULLAGER, P.D., and BOTTINO, M.L. 1968. Radiometric age of the volcanics at Ar1sa1g. Nova Scot1a and the Ordovician-S1lurian boundary. Canadian Journal of Earth Sclences, 5, pp. 311317 .

HURST, J.M. and PICKERILL, R.K. 1986. The relationsh1p between sedimentary facies and faunal associations in the Llandovery siliciclastic Ross Brook Formation, Ar1sa1g, Ant1gonish County. Nova Scot1a. Canadian Journal of Earth Sciences, 23. pp. $705-726$.

KEPPIE, J.D. 1982. Tectonic map of Nova Scotia. Nova Scot1a Department of Mines and Energy, Map 82-3, Scale 1:500,000.

KEPPIE, J.D. 1987. The Appalachian Collage; International Geological Correlation Program. Caledonide Orogen Volume. Uppsala Meet1ng. Edited by D.G. Gee and B. Sturt. J. Wiley and Sons.

KEPPIE, J.D., DOSTAL, J. and ZENTILLI, M. 1978. Petrologg of the early S1lurian Dunn Point and McG1ll1vray Brook Formations. Nova Scot1a Department of Mines and Energy. Paper $78-5,20 \mathrm{p}$.

KEPPIE, J.D. and SMITH P.K. 1978. Comp1lation of 1sotop1c age data of Nova Scotia. Nova Scotia Department of Mines, Report $78-4$; 110 p.

MAEHL. R.D. 1961. The older Paleozo1c of P1ctou County, Nova Scotia. Nova Scotia Department of Mines, Memoir 4.

MURPHY, J.B. 1987. Petrology of Upper Ordovician-Lower Silurian rocks of the Ant1gonish Highlands, Nova Scot1a. Canadian Journal of Earth Sclences, 24, pp. 752-759.

MURPHY, J.B. 1986. Geology of the western Ant1gonish H1ghlands, Nova Scot1a. In Current Research, Part A, Geolog1cal Survey of Canada, Paper 86-1A, pp. ?

MURPHY, J.B. 1985. Geological map of central and southern Antigonish Highlands. Geological Survey of Canada, Open File 1181.

MURPHY J.B. 1984. Geology of the southern Antigonish Highiands, Nova Scotia. In Current Research, Part A Geological Survey of Canada, Paper 84-1A, pp. 587-595.

MURPHY, J.B. and KEPPIE, J.D. 1987. The strat1graphy and depositional environment of the Late Precambrian Georgeville Group, Antigonish H1ghlands, Nova Scotia. Maritime Sediments and Atlant1c Geology, 23, pp. 49.

MIRPHY J.B. KEPPIE, J.D. and HYNES, A.J. 1982. Geology of the northern Ántigonish Highlands. Nova Scot1a Department of Mines and Energy, Report 80-1, pp. 103-108.

MURPHY, J.B.. KEPPIE, J.D. and HYNES, A.J. In press. Geology of the northern Antigonish Highlands, Geological Survey of Canada, Memoir.

PICKERILL R.K. and HURST, J.M. 1983. Sedimentary facies, depositional environments, and faunal associations of the lower Landovery (S1lur1an) Beech111 Cove Formation. Ar1sa1g. Nova Scot1a. Canadian Journal of Earth Sc1ences. 20, pp. $1761-1779$.

SMITH, P.K. 1979. A note on the geology and Silurlan fossil occurrences south and west of Kenzieville, Ant1gonish Highlands. Nova Scotia Department of Mines Report of Activities, Report 79-1, pp. 89-94.

WILLIAMS, $H$. 1978. Tectonic L1thofacies map of the Appalachian Orogen. Memorial Un1versity of Newfoundland, Map No. 1. 